\title{
Investigating the Challenges Faced by Microfinance Institutions in Ghana: Evidence from Takoradi
}

\author{
Daniel Odoom ${ }^{1}{ }^{*} \quad$ Kennedy Oppong Fosu ${ }^{2} \quad$ Kwadwo Ankomah $^{3} \quad$ Marian Birago Amofa $^{4}$ \\ 1. Research Coordinator, Ghana Technology University College, Takoradi Campus \\ 2. Finance Manager, Ghana Technology University College, Takoradi Campus \\ 3. Lecturer, Ghana Technology University College, Takoradi Campus \\ 4. MBA Scholar, Ghana Technology University College/Coventry University
}

\begin{abstract}
Micro Finance Institutions (MFIs) contribute immensely to the economy of every nation. Particularly, within the informal sector, MFIs constitute the pivot around which many financially disadvantaged individuals rely on in terms of access to finance for their businesses. MFIs play a tremendous role in the poverty reduction and employment creation agenda of many nations including Ghana. Notwithstanding the immense role MFIs play in the economies of nations, there is a wide recognition of the fact that the institutions can perform better if they are able to overcome the challenges they face in their operations. However, in order for MFIs to effectively tackle the challenges they encounter, it is important for them to first identify and appreciate these challenges and the threats they pose to the effectiveness of their operations. Within this context, this study sought to explore the challenges MFIs in Ghana face, with particular emphasis on those operating in Takoradi. The study was quantitative, with descriptive survey as the design. Managers and employees of MFIs located in the city licensed by the Bank of Ghana were involved in the study. Simple random sampling method was used to select 114 respondents for the study and questionnaire was relied upon for data collection. The researchers used frequencies, percentages, an independent samples t-test and ANOVA as tools for data analysis. The study observed that increased competition in the industry, low repayment rates, higher cost of information technology, low level knowledge of operators, inadequate and expensive infrastructure base, high capital requirements, unfavourable regulation and supervision, inadequate employee incentives, and erosion of public confidence in MFIs were ranked as major challenges in the industry. A significant difference existed in the perception of male and female respondents on the challenges MFIs in the city faced. However, there was no statistically significant difference in educational qualifications of respondents and their views on the challenges MFIs in Takoradi faced. It is recommended that MFIs in the city should invest in staff development for all levels, from senior level to junior level. Also, Managements of MFIs should put in place adequate measures to educate their clients on the need to pay their loans and also institute appropriate sanctions to deal with loan defaulters. This will also require MFI to ensure credit worthiness of clients before granting them loans. Again, the Managements of MFIs should come out with appropriate measures to incentivize their employees so as to avoid possible cases of poaching.
\end{abstract}

Key Words: Challenges, Development, Financial Institutions, Microfinance, Financial System, Poverty

DOI: $10.7176 /$ RHSS/9-10-13

Publication date:May $31^{\text {st }} 2019$

\subsection{Introduction}

Globally, microfinance has emerged as a leading and effective strategy for poverty reduction. It has the potential for transforming the lives of the poor. Microfinance entails the provision of financial services and the management of small amounts of money through a variety of products and services. It also has a system of intermediary functions that are targeted at low income clients. MFIs provide loans, savings, insurance, transfer services and other financial products and services aimed at helping very poor people to meet basic needs and protect them against risks. There is a wide recognition that MFIs support women's economic participation which is critical in promoting gender equity (Bank of Ghana, 2007).

Historically, microfinance was pioneered by dedicated non-governmental organizations (NGOs) and banks including Grameen Bank (Bangladesh), Kenyan Rural Enterprise Programme (K-Rep) (Kenya), Bank Rakyat Indonesia (BRI) Unit Desa (Indonesia), Fundación para la Promoción y Desarrollo de la Microempresa (PRODEM), Banco Solidario (BancoSol) (Boliva), and many others. These confronted the conventional wisdom of the 1970s and found that with new lending methods, the rural poor repaid loans without delays. In fact, these new methods included providing very small loans without collateral at full-cost interest rates that were to be repaid in instalments. There was a growing conviction that the poor who are often excluded from the formal 
financial sector, can, be a market niche for innovative banking services that can be commercially sustained (UNDP, 1999).

Microfinance helps to create access to productive capital for the poor. This asset, together with human capital and social capital helps to move people out of the quagmire of poverty. The sense of dignity of the poor is strengthened through providing them with material capital, which enables them to participate in the economy and society (Otero, 1999). The aim of micro-finance is simply not about providing capital to the poor to combat poverty on an individual level, it also has a role at an institutional level (Otero, as cited in Bank of Ghana, 2007). MFIs seek to deliver financial services to the poor, who are constantly ignored by the mainstream financial sector. In the views, of Littlefield and Rosenberg (2004), the poor are often excluded from the formal financial sector of the economy. This gap is what MFIs seek to address within the broader context of market failure. By addressing this gap in the market in a financially sustainable manner, an MFI can become part of the formal financial system of a country and so can access capital markets to fund their lending portfolios, allowing them to dramatically increase the number of poor people they can reach (Bank of Ghana, 2007; Otero, 1999).

MIFs play a crucial role in the economies of many nations. It has been observed that MFIs contribute immensely to poverty reduction and employment creation in many countries, with their overall impact on improved economies (Baten, 2009). MFIs have been found to contribute in expanding financial access to the poor and the marginalized in the society. According to Odoom, Fosu, Ankomah and Amofa (2019), MFIs contribute immensely to the Ghanaian economy especially in areas such as income generation, employment creation, financial literacy and women empowerment. Other contributions of MFIs to the local economy of Ghana include providing financial capital to people, support for small and medium scale businesses, and asset creation tools. In spite of the critical role of MFIs in Ghana, many of these institutions are struggling to survive. For instance, in the year 2015, about 70 MFIs had their licenses revoked by the Bank of Ghana, which is the regulatory agency. Several MFIs have failed to maintain their operations in the country. What is more is that between the years 2013 and 2015, about 100 MFIs collapsed resulting in several problems for their clients. Beyond the psychological blow such collapses cause to people, the situation erodes confidence in the industry (Obour, 2013; Odoom et al., 2019; Otoo, 2015).

In essence, there is a growing understanding among academia and policymakers that microfinance is an important tool in the poverty reduction efforts. However, it is believed that for microfinance to meaningfully contribute to poverty reduction its related development challenges should be addressed. When the opportunities within the sector are properly harnessed it can indeed make sustainable contributions to poverty reduction (Bank of Ghana, 2007). The collapse of these MFIs in Ghana raises a bigger issue about the challenges the institutions face in their operations. Again, although many studies conducted including Obour (2013), and Odoom et al. (2019) revealed the tremendous contributions of MFIs to the economy of Ghana, they failed to properly interrogate the challenges within the sector. Specifically, the usefulness of the studies done by Baten (2009), Obour (2013), and Odoom et al. (2019) on MFIs is limited to the extent that they could not clearly articulate the challenges the institutions face in their operations. The apparent gap in these studies potentially obliterates efforts to bring clarity to the operational issues and consequences of MFIs within the economy. Besides, the failure to properly bring out the challenges faced by MFIs compounds attempts to better locate the place of MFIs within the broader spectrum of national development and financial inclusion mechanisms. It is against this backdrop that this study sought to investigate the challenges within the MFI sector and proffer measures for improvement, by focusing on MFIs in Takoradi.

\subsection{Purpose of the Study}

The study aimed at investigating the challenges MFIs face within the Ghanaian economy by relying on the situation in Takoradi.

\subsection{Research Objectives}

1. To ascertain the challenges microfinance institutions in Takoradi face.

2. To determine whether or not differences exist in the views of male and female respondents with respect to the challenges MFIs in Takoradi face.

3. To determine whether or not differences exist in educational levels of respondents and their views on the challenges MFIs in Takoradi face.

\subsection{Research Hypotheses}

$\mathrm{H}_{0}$ : There is no significant difference in the views of male and female respondents with respect to the challenges MFIs in Takoradi face. 
$\mathrm{H}_{1}$ : There is significant difference in the views of male and female respondents with respect to the challenges MFIs in Takoradi face.

$\mathrm{H}_{0}$ : There is no significant difference in educational levels of respondents and their views on the challenges MFIs in Takoradi face.

$\mathrm{H}_{1}$ : There is significant difference in educational levels of respondents and their views on the challenges MFIs in Takoradi face.

\section{Overview of Literature}

\subsection{Theoretical Framework}

\subsubsection{Neo-classical economic model}

Several neo-classical economic theorists including (Jevons, 1971; Menger, 1871) outlined several perspectives on the factors that results in growth. According to these neo-classical theorists, an increase in the economy at the long term often requires a rise in the supply of labour and improvement in labour and capital productivity. Thus, according to Weintrub (2002), these scholars further added that improvement in productivity often focuses on exogenous variables and this literally means that the variable is perceived to be free of capital investment. These studies are based on fundamental assumptions which include:

i. People have rational preferences among outcomes,

ii. Individuals maximize utility and firms maximize profits,

iii. People act independently on the basis of full and relevant information.

Conclusively, the implication of the neo-classical economic theory is that, the hard work and effort of business owners facilitate the development of small business, since there is the use of entrepreneurial skills that discover the niches of business, strategies pertaining to effective marketing and an efficient management of business and not just been dependent on additional funds external to the business.

\subsubsection{Breaking the Vicious cycle of poverty theory}

The studies of Vincent (2005) outline issues relating to poverty in accordance with microfinance institutions in two main questions and these include;

i. "To what extent is entrepreneurship empowered by microfinance in less developed countries, and are these procedures economically and environmentally viable?"

ii. "To what extent do real-world case studies imply that these procedures minimize poverty in less developed economies with regards to the economic development procedure?"

Vincent (2005) is of the view that the interference of microfinance institutions provides the platform where the poor have the opportunity of breaking their vicious cycle of poverty as illustrated in Figure 2.1. From the diagram, it can be seen that, the poor are been described by their low productivity, low per capita income, low savings and low gathering of capital. How the poor is able to come out from this cycle is facilitated by growth in the economy and this often results in total socio economic growth. That, economic growth serves as the process that focuses on the improvement and the quality of the human livelihood. The cycle integrates three main equal significant aspects that increases income and consumptions, foster self-respect as institutions provide opportunity for human dignity and increase in the liberation of the individual. 


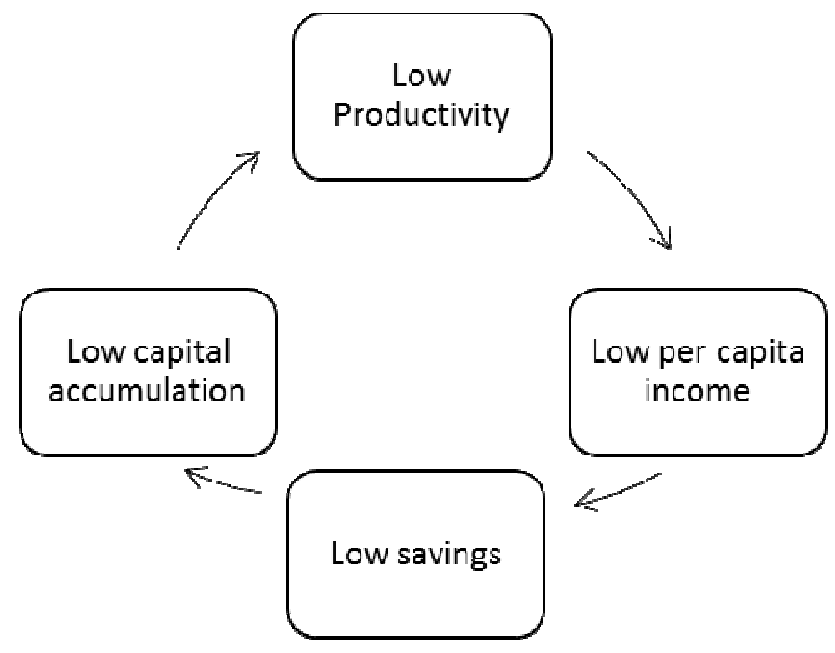

Figure 2.1: The Vicious Cycle of Poverty

Source: Vincent, as cited in Amofa (2018)

Moreover, according to Robinson (2002), the initial act of several less privileged families when there's income increase is to enrich their meals and give their offspring good education which is basic to the growth of an economy. When a platform is created for the poor/ and the less privileged, they extend their productive ventures which lead to a rise in income, personal belongings, and eventually increased confidence.

2.1.3. The Model of Impact Chain

According to Hulme (2000), the model of impact chain was developed by Sebstad et al. (1995). In the programs of the microfinance institutions are based on the assumptions, that they often intervene on the behavior of humans and practices, as this provides the capital for humans to achieve or increase their profitability in their respective business. These forms of intervention approach can be assessed on the differences of values on the main variables that exist between the outcome of a business owner, enterprise, household and population. This is often experienced on an intervention against the values of the variables that would have happened if there had not been any intervention. The reality that there will not be any agent that may have an interference and similarly not have an interference, has the potential of generating several methodological issues. This is due to the fact that, most changes are being influenced based on mediated processes and procedures which may affect the behavioral change and the outcome in ways that may be very challenging to predict. As stated by Sebstad et al. (1995), the presence of MFIs paves the way for individuals and household to impact on their state of livelihood.

\subsection{Conceptual Base of the Study}

2.2.1. The Concept of Microfinance

Microfinance is the provision of financial services for the poor and the less privileged in society. Microfinance services include savings, transfers, insurance and credits. Its products are tailored to the demographics, financial relationships and needs of the poor and the less privileged. Microfinance means building financial systems that serve the poor and the less privileged. Microfinance means building financial systems that serve the interest of the poor (Fiji National Microfinance Workshop, 2009). By so doing, MFIs enable women clients to be empowered through the provision of financial services and mechanisms. They take service to the poor and the less privileged. MFIs work to ensure client participation; and incentivize repayment and loyalty (Fiji National Microfinance Workshop, 2009).

Microfinance is regarded as the attempt to improve access to small deposits and small loans for poor households neglected by banks. This means microfinance ensures the provision of financial services to the less privileged, the disadvantaged, low-income, and poor self-employed people in society. It also offers opportunities for the non-bank low income and poor households to have to deposits and credit facilities (Schreiner and Colombet, 2001). Microfinance is also explained as the provision of a broad range of financial services such as deposits, loans, payment services, money transfer and insurance to the poor and low-income households and their microenterprises (Opoku Antwi, 2015). It entails efforts to offer various financial services and activities to the less privileged and the poor people in society with the sole aim of improving upon their living conditions. These services and activities help to provide livelihood activities required for human survival and well-being. 
In the views of Asiama and Osei, as cited in Odoom et al. (2019), micro financing offers financial services to self-employed or low income poor people in society. Micro financing is defined as the effort to enhance availability of minor deposits and credit for needy households (Schreiner, 2001). Micro financing involves meeting the financial needs of the poor and the less privileged who are mostly found in rural and urban areas with services such as savings, loans and insurance (Odoom et al., 2019). In the views of Westover (2008), microfinance is as a way by which financial services are made available to the poor or clients with low income who are often excluded from any traditional financial system as a result of lack of collateral, stable employment and a verifiable history of credit. A collection of banking practices established around the provision of small loans, usually collateral-free, and acceptance of micro savings deposits is microfinance. Microfinance is a product of innovation in the saving and loan mechanism. In another sense, microfinance illustrates the incorporation of financial needs to individuals into a national mainstream financial system (Armendariz and Morduch, 2005; Fisher and Sriram, 2002).

MFIs operate as a small scale financial service provider with a focus on providing credit and savings to individuals. These individuals often operate micro enterprises involved in micro-production, recycling, repairing and service provision (Marguerite, 2001; Odoom et al., 2019). Microfinance also engages them in productive activities or enable them to grow their small business over a period of time. Currently, most MFIs inculcate an extensive array of services including offering credits, savings, insurance, money transfer facilities to meet the various financial needs of the less privileged in society (Hagen, 2004; Odoom et al., 2019). From the above, microfinancing can be explained as the attempts to offer various financial services such as payment services, savings, credit facilities, insurance and money transfers to the less privileged, the disadvantaged, low-income, and poor self-employed people in society in order to improve their lives.

\subsubsection{Models and Schemes of Microfinance Institutions}

Various models and schemes are often employed by operators of MFIs to achieve their set goals and objectives. The various schemes are used based on the choice of administrative strategy being used by the MFI or the prevalent external factors of the base community. Below are some of the schemes of MFIs:

\subsubsection{Rotating Savings and Credit Associations}

Rotating saving and credit associations model refers the situation by which individuals come together to form a group where regular contributions are made in a cyclical order towards a common fund. The lump sum is then given to one of the members in each cycle (Grameen Bank, 2000). Harper (2002) was of the view that, the model serves as an approach to save and credit. This literally implies, members of a group are made of friends and neighbours, therefore opportunity for social interaction is provided and also group peer pressure exists. Groups are usually made up of four to ten people. Also, members collectively guarantee the repayment of loan to a member and access to subsequent loans to any other member is based on a successful repayment of previous loans taken. Accordingly, payments are usually done on weekly or monthly basis. Additionally, solidarity groups have proven to be effective in deterring defaults, and this is evident of the rate at which loans are repaid experienced in set-ups like the Grameen Bank that uses this model of micro financing. And for the past decade, the use of this model has been very efficient when it comes to repayment of loans (Harper, 2002).

\subsubsection{Village Banking}

These are often community managed financial credit and saving associations that are usually created by NGOs to help community members accumulate savings and improve on their livelihood through the provision for financial services. The savings of group members sometimes makes up the entire capital base. For the past three decades, this model has been practiced, and according to a report from the Grameen Bank (2000), it has been able to help people with low income to improve on their lives based on activities that will enable them to become self-employed. However, these same people facilitate the operation of the bank, select their own officers, create their own by-laws, disburse loans to individual beneficiaries and collect repayments. According to a report from Global Development Research Center (2005), such loans to individuals are backed by moral collateral.

Additionally, the loan capital sponsored by the MFI to the village bank is consequently lent to members in the village. To make provision for collective guarantee, all beneficiaries testify to a loan agreement with the village bank. However, it is often required of members to save up to 20 percent of the loan amount each cycle. Savings from members are committed to a loan amount which is used in financing new loans or collective incomes that have been generated, and this is supposed to remain in the village. With this model, savings accrues no interest, however, portions of the profit from the village bank's relending activities is given to members. It is anticipated that, participants enhance their social status by means of engaging in self-employed activities. The major distinction between this model and that of Grameen's is the aim to accumulate capital to become autonomous 


\subsubsection{Cooperatives}

As an organisation, a cooperative is owned by its members who come together voluntarily to solve their economic, social and cultural problems. Basically, cooperatives are founded on the understanding that there exist sufficient resources, human and financial, to enable every community manage their own financial operations. According to Nasir (2013), the owners are members from various sectors of the community including commerce, agriculture, small scale mining, which uses the services through a jointly-owned and democratically-controlled enterprise. Those engaged in micro financing have the tendency to reach micro-entrepreneurs and the economically active higher segment of the low-income population (OECD, 2007). The Grameen bank established by the Nobel Peace Prize winner Prof. Yunu is of this model. This setting is made up of for instance about five persons out of which two are chosen and given loans. Other loans are released to the other members based on the repayment of the earlier loans. Hence it's a collective responsibility and social collateral at work. Members are all jointly responsible for the actions of one another. Some of the features are low transaction cost, no collateral; loans are paid in small amounts within short intervals with little paper work. Also, a co-operative can be formed by a group of middle or upper class individuals to offer microfinance services to the poor (Amofa, 2018).

\subsubsection{Credit Unions}

Brown (2011) has defined a credit union to be a financial cooperative (non-profit) owned and controlled by its members with the aim of disbursing credits and collecting savings. Srinivas (2015) suggests that the outreach of credit unions is usually fairly limited due to their structure (only providing financial services to members) which is additionally restricted by the low level of capital growth. Members are people of a common bond: labour union, social fraternity, religious group etc. Compared to community banks, these are smaller and interest rates charged are merely for sustainability (Amofa, 2018).

\subsubsection{NGOs}

Non-Governmental Organisations refer to any organization that is not controlled or managed by a government. It is not-for-profit and external organizations which work towards the development of communities (Funds for NGOs, n.d.). They are external to beneficiaries. The activities of NGOs include offering microfinance services (loans, insurance, savings, etc.) as well as creating opportunities for participants to upgrade their knowledge on the principles and method of microcredit which include workshops and seminars, and training programmes (Srinivas, 2015). Their sources of funds are usually from donor agencies and world bodies and sometimes play the role of an intermediary between the poor and donor agencies. Examples are ACCION International in the US.

\subsubsection{Group Model}

This model is grounded in the philosophy that any shortfalls an individual may face is overcome by the collective responsibility and security created with the formation of a group. Some of the benefits of creating a collective body includes: education and building awareness, collective bargaining power, peer pressure etc. For instance, joint liability groups, self-help groups (Amofa, 2018).

\subsubsection{Individual Lending}

This is a straight forward model of lending where micro loans are given directly to the borrower. Usually it forms part of a bigger 'credit plus' programme, in which different socio-economic services including development of skills, education, and several outreach programmes are provided (Amofa, 2018).

\subsubsection{For Profit Banks}

They include commercial banks, specialized Microfinance Banks that offer varied financial services to the needy and less-privileged but its major aim is to gain high returns on their investments. Unlike some other models, whiles it seeks to contribute to social development, it is more committed to progressing financially, beyond mere sustainability. The above are general schemes/ models provided under micro financing. However, in various countries microfinance are grouped severally. These may be according to form of ownership, services provided, lending styles etc. (Amofa, 2018). For instance, in India microfinance institutions are grouped into four; Joint Liability Group, Self Help Group, Grameen Bank Model and Rural Cooperatives (Singh, 2016). In Nigeria, there are five types, and they are grouped according to ownership; Community Banks, Privately Owned Microfinance Institutions, Government Microfinance Institutions, Non-Government Organization (NGO) Owned Microfinance Institutions and Foreign Owned Microfinance Institutions (Amofa, 2018; Zuru et al., 2016).

In Kenya, MFI groupings are Deposit-taking and Non-deposit-taking MFIs. And under the deposit-taking, they 
are further categorized into two. First, are the Community MFIs whose activities are within a specified district, city or region. Second, are the Nationwide MFIs licensed to carry out activities countrywide. Whilst a community MFI can be converted into a nationwide MFI with approval from regulators, the reverse cannot be (Amofa, 2018; Microfinance Act 2006). However, in Ghana, MFIs are grouped into three, making microfinance services available to the urban and rural poor and underserved portions of the economy. These comprise Tier One- Formal Suppliers of Microfinance (including rural and community banks, savings and loans companies, commercial banks), Tier Two- Semi-Formal Suppliers of Microfinance (including credit unions, cooperatives, financial non-governmental organizations (FNGOs)), and Tier Three- Informal Suppliers of Microfinance (including rotating and accumulating savings and credit associations (ROSCAs and ASCAs), traders, susu collectors and clubs, moneylenders and other individuals) (Brown, 2011).

\subsubsection{Challenges of Microfinance Institutions}

Many of the failures experienced by micro financing and community banking scheme were predicated on the challenges they faced. Microfinance banking is still facing some of these challenges (Ikechukwu, 2012; Opoku Antwi, 2015). Several collapses unprecedented in the MF industry happened in 2013 despite the fact that minimum requirements for licensing by Bank of Ghana, the regulator had been met (Addo, 2014). Below are some of the challenges MFIs face:

\subsubsection{Poor Policy Guidelines}

There have been no specific policy guidelines and goals regarding the microfinance sub-sector, since the 1950 s. This accounts partially for the gradual progress as well as apparent lack of direction and coordination. No coherent approach has so far been applied to deal with constraints hence affecting decision making and implementation (Asiama and Osei, 2007). Addo (2014) argues that MFIs were never meant to play the role of commercial financial intermediaries, hence, branch opening and transacting business as commercial banks do not make them so. He continues, that they indulging in overtrading is as a result of the absence of competent staff. For example, instead of investing funds to at least break even on interests given to customers; rather these timed investments were regarded as free or idle funds which were wrongly used. In several instances, funds of depositors have been used to open new branches and make other enormous capital expenses (costly rents, furniture and decorations). Little did they consider, that opening branches means increase in expenditure on utility, salaries and other overhead expenses. Thus, no clear guidelines and policies for MFI operations (Amofa, 2018; Lartey, 2016).

\subsubsection{Payment of Higher Interest Rates on Investment}

A study by Owusu-Nuamah (2014) portrays the Ghanaian market as being financially saturated because so many MFIs are springing up everywhere. Therefore, institutions came up with products that will attract a lot more customers in a bid to keep up with the pressure of competition. He further states, that some of these products have been too costly to the institutions; thus, some of the costs incurred in the form of interest payments to clients could not be covered by their streams of income. Popular amongst these were investments into the cement and cloth business. They were run similarly to fixed deposits. Thus, clients were to deposit about GHC100.00 (for majority of the institutions) in exchange for $1 / 2$ piece of cloth or a bag of cement that cost about GHф20.00 for 4-6 months (dependent on available competition) (Amofa, 2018; Opoku Antwi, 2015).

\subsubsection{Inadequate Knowledge of the Industry by Owners of MFIs}

Principally micro financing aims at making available loans to the poverty-stricken at affordable rates in an effort to draw them out of poverty or dire circumstance (Khan, 2008). It is therefore, required of this industry to have a more specialized financial knowledge and a unique combination of skills, including knowledge of social science, local languages and customs as well. Contrary, several owners, commonly the Chief Executive Officers (CEOs), run the business as a trade and usually established their own after a short period of training in other MFIs. Some owners showed no concern to analyzing the consequences of their decisions. Counsel from young financial professionals to the business were ignored, and since they have no option, permit owners to have their way so as to maintain their jobs (Opoku Antwi, 2015; Owusu-Nuamah, 2014). Most owners run their institutions as they seemed fit, with less or none managerial consultation whatsoever. Truly, inadequacy of government and management is to be blamed for the major setbacks MFI community has gone through (Khan, 2008). Good corporate governance can enhance firm performance and ensure long-term existence. Issues relating to corporate governance have increasingly become a source of interest in microfinance because it is currently considered one of the ineffective areas in the industry (CSFI, 2008). Too much concentration of managerial authority in owners, alongside the absence of best practices like shareholder ownership and independence of board remain some of the primary reasons for MFIs failure (Amofa, 2018). 


\subsubsection{Poor Recovery Rate}

MFIs were formerly established to assist in financing micro-enterprises on a small scale and local economic activities that were mostly ruled out from formal finance and mainstream banking practice (Siwale and Ritchie, 2011). Poor rate of recovery, inadequate capital for sustainability, inadequate credit delivery and management, inability to reach the most vulnerable and marginalized, regulation and supervision challenges as well as high turnover of staff of MFI are some of the challenges plaguing Microfinance in Ghana (Boateng et al., 2015). Loans have been the main source of income for microfinance institutions. However, this division which needs intensive assessment has not received the necessary concentration required. The usual approach of requesting for clients to contribute for one month or two in order for their balances to be doubled or tripled downplays the importance of proper loan assessment and monitoring. For most companies, the ratio of loan officer to client expands, hence not enough time available for attention on loans that were defaulting till loans hit the expiry region (by which time it is highly difficult to reclaim). This loophole was recognized by clients and used it to their advantage by taking from Peter to give to Paul (Opoku Antwi, 2015; Owusu-Nuamah, 2014)

\subsubsection{Staffing}

There usually is an overlap in some cases of roles and responsibilities of stakeholders. The overlap is due partly to the poor definition of reporting relationship among organizational and institutional hierarchy. Mukama et al., as cited in Addo (2014) state that staff related issues, including educational levels, development of skills, and suitable incentive schemes for staff can affect the survival of MFIs negatively if not properly addressed. Staffing and competency levels are still below what is desired, because of their inability to attract and retain high level staff due to poor staff remuneration packages. MFIs are therefore grappling with high employee turnover.

2.2.3.6. Fraudulent Activities by Staff

Fraudulent actions by staff of the institutions are one major cause for MFI failures. Poor bookkeeping practices and software, weak internal controls and insufficient supervision are contributory factors to this challenge. Ghost accounts are created either to take loans or record fake expenditure whiles others under record certain deposits especially where field staff are many and not properly regulated. There are also peculiar cases where there are no or low level restriction on companies' software, giving employees inordinate access. Therefore, some staff is able to delete certain withdrawals so their account balance doesn't reflect the withdrawals (Owusu-Nuamah, 2014).

\section{Methodological Framework}

The quantitative research approach was adopted in this study, with descriptive survey as the design. Aggarwal, as cited in Odoom et al. (2019) maintains that descriptive studies enable researchers to gather information on current situations with the aim of interpreting the issues at stake. Scholars including Babbie (2004), and Shuttleworth (2013) opine that descriptive surveys involve making observation and descriptions of phenomena without any manipulation or in an unbiased way. The study focused on the 16 MFIs in the city licensed by the Bank of Ghana. The sixteen (16) licensed microfinance institutions are: Af Microfinance Company Limited, AStar Microfinance Limited, Cashpoint Microfinance Limited, Coastal Commerce Microfinance Limited, Daily Capital Microfinance Limited, Donewealth Microfinance Limited, Ebenezer Microfinance Company Limited, First Rate Microfinance Limited, Loan Line Microfinance Limited, Mallon Microfinance Company Limited, Oye Microfinance Limited, Premier Microfinance Limited, Rogai Microfinance Limited, Startwell Microfinance Company Limited, Unik Life Microfinance Limited and Yaalex Microfinance Limited. The population for the study consisted of managers, assistant managers and employees of the selected MFIs. The population size of the 16 MFIs was 160. Based on this figure (160), 114 respondents were selected for the study using Yamane's (1967) sample size determination formula. A closed-ended questionnaire was used to collect relevant data for the study, with frequencies, percentages, an independent samples t-test and ANOVA as the analytical tools.

\section{Results and Discussion}

The results and discussion was done in two parts. The first part looks at the background characteristics of respondents, whilst the second part considers the results based on the specific research objectives. In terms of sex composition, the study revealed that the majority $(52.6 \%)$ of the respondents were males, with females constituting 47.4 percent of the respondents. With regard to the working experience of the respondents, the study found that 49.1 percent had worked below five years, 33.3 percent had spent between 5 and 9 years whilst 13.2 percent had worked between 10 and 14 years. This means that the majority $(50.9 \%)$ had worked for at least years or more in their respective MFIs as shown in Table 1. This implies that they have enough information on the current state of the institutions to provide an accurate assessment of the state of the MFIs. The finding also indicates that staff retention level is not bad in the institutions. However, this study could not confirm the findings of Muhammad (2010) and Lartey (2016) which state that the absence of technical expertise and depth of experience, financial acumen of staff is a challenge for the microfinance industry. 
Table 1: Working Experience of Respondents

\begin{tabular}{|l|l|l|}
\hline Years' Spent & Frequency & Percentage \\
\hline Less than 5 years & 56 & 49.1 \\
\hline $5-9$ years & 38 & 33.3 \\
\hline $10-14$ years & 15 & 13.2 \\
\hline Over 14 years & 5 & 4.4 \\
\hline Total & 114 & 100.0 \\
\hline
\end{tabular}

Source: Field data (2018)

On the issue of the category of respondents, the study found that 55.3 percent were junior level employees, whilst 17.5 percent were senior level employees. By implication, the majority $(55.3 \%)$ of the respondents were junior level employees as observed in Table 2. Within an institution, employees are ranked on their occupational category, ranging from junior level, middle level and senior level staff. Middle level staff are privy to more information than junior level staff and senior level staff are privy to more internal and shareholder information than middle level staff. However, they all have substantive information on the workings of the organization.

Table 2: Categories of Respondents

\begin{tabular}{|l|l|l|}
\hline Category & Number of Respondents & Percentage \\
\hline Senior Level Employee & 20 & 17.5 \\
\hline Middle Level Employee & 31 & 27.2 \\
\hline Junior Level Employee & 63 & 55.3 \\
\hline Total & 114 & 100.0 \\
\hline
\end{tabular}

Source: Field data (2018)

Regarding the educational level of respondents, Table 3 shows that 69.3 percent of them had SSCE, 17.5 percent had HND/Diploma, whilst 10.5 percent had obtained first degree. In effect, the majority $(69.3 \%)$ of the respondents had SSCE/WASSCE as their highest educational qualification.

Table 3: Educational Level of Respondents

\begin{tabular}{|l|l|l|}
\hline Category & Frequency & Percentage \\
\hline SSCE/WASSCE & 79 & 69.3 \\
\hline HND/Diploma & 20 & 17.5 \\
\hline $1^{\text {st }}$ Degree & 12 & 10.5 \\
\hline $2^{\text {nd }}$ Degree & 3 & 2.6 \\
\hline Total & 114 & 100.0 \\
\hline
\end{tabular}

Source: Field data (2018)

The first research objective explored the challenges microfinance institutions located in Takoradi face in their operations. Several issues such as expanding access to credit, improvement in incomes and poverty reduction. Respondents were asked to classify the challenges based on a five likert scale in terms of intensity. They were required to indicate the intensity of stated challenges. The challenges that the MFIs' staff responded to included: high capital requirements, lack of qualified staff, poaching of staff by other microfinance business, inadequate and expensive infrastructure base, low credit delivery and management, unfavorable regulation and supervision, increased competition in the industry, limited management capacity, high cost of information technology, low level knowledge of clients, poor macroeconomic policies, lack of qualified research team, low repayment rates, low investment in agriculture development, among others.

The study observed that the issue of lack of policy guidelines was not a challenge $(\mathrm{M}=1.0, \mathrm{SD}=1.43)$. The respondents disagreed to the fact that there were no policy guidelines governing the operations of MFIs in the city. The finding contrasts Asiama and Osei's (2007) observation that no clear policy guidelines exist to regulate the activities of the MFIs in Ghana. This finding rather supports that of Opoku Antwi (2015) which showed that 
policies existed to guide the operations of MFIs in Ghana. However, the challenge has been the apparent failure of MFIs in the country to comply with these policies (Opoku Antwi, 2015).

Additionally, the study revealed that poor macroeconomic policies constituted a challenge $(\mathrm{M}=4.0, \mathrm{SD}=0.635)$ to the operations of the MFIS. A poor macroeconomic policy affect interest rates, demand for funds and slows down enterprise. When cost of living is high, demand for goods and services reduce, hence slows down business and a ripple effect on demand for funds by entrepreneurs. On the other hand, even when loans are taken repayment becomes a burden. This is in agreement with the findings of Crabb (2008) which state that external factors such as macroeconomic conditions have direct influence on a country's finance sector.

Furthermore, the researchers discovered that high interest rates was another obstacle $(\mathrm{M}=4.0, \mathrm{SD}=1.232)$ to the effectiveness of MFIs in the city. However, in terms of magnitude the issue of high interest was a moderate challenge. The present study coincides with Opoku Antwi (2015) who found that high interest rates was one challenge leading to the collapse of microfinance institutions in Ghana. However, in terms of magnitude, the finding deviates from Opoku Antwi's (2015) contention which showed that high interest rates was the leading challenge faced by MFIs in Ghana.

Similarly, the quest by MFIs to be more technology savvy in the 21 st century is a challenge. The respondents stated that higher cost of information technology was a major challenge hampering the effectiveness of the institutions. The institutions were therefore unable to rely adequately on information technology to improve upon their operations of the companies. This agrees with the findings of Boateng and Agyei (2013) which state that one of the major challenges of microfinance in the $21^{\text {st }}$ century, the age of information technology, is its high cost.

Table 4: Views of Respondents on the Challenges MFIs face in the city

\begin{tabular}{|l|l|l|}
\hline Challenge & Mean & Standard Deviation \\
\hline Lack of policy guidelines for MFIs & 1.0 & 1.434 \\
\hline Poor macroeconomic policy framework & 4.0 & 0.635 \\
\hline Increased competition in the industry & 5.0 & 0.564 \\
\hline Low repayment rates & 5.0 & 0.544 \\
\hline High interest rates & 4.0 & 1.232 \\
\hline Higher cost of information technology & 5.0 & 0.674 \\
\hline Low level knowledge of operators & 5.0 & 0.832 \\
\hline Inadequate and expensive infrastructure base & 5.0 & 0.434 \\
\hline High capital requirements & 5.0 & 0.764 \\
\hline Low credit delivery and management & 4.0 & 1.674 \\
\hline Limited management capacity & 4.0 & 0.972 \\
\hline Unfavourable regulation and supervision & 5.0 & 1.234 \\
\hline Inadequate qualified staff & 3.0 & 0.864 \\
\hline Limited management support for capacity building & 5.0 & 0.522 \\
\hline Inadequate employee incentives & 5.0 & 0.433 \\
\hline Poaching of staff by other microfinance business & 4.0 & 1.072 \\
\hline Erosion of public confidence in MFIs & 5.0 & 0.544 \\
\hline Inadequate investment in agriculture development & 4.0 & 0.899 \\
\hline Scale: 5=High 4=Moderate & & $1=$ Disagree \\
\hline Source: Field data (2018) &
\end{tabular}

Besides, increased competition was found as a high challenge in the industry $(\mathrm{M}=5.0, \mathrm{SD}=0.56)$. With the rise in the number of MFIs, competition in the industry has increased and has become a great challenge to MFIs. The present study substantiates the views expressed by Ghosh (2013) that increased competition constitutes a challenge to the microfinance sector. The author explained further that extreme competition in oversaturated markets pressurizes MFIs to lend to riskier borrowers. It is of little wonder then that low repayment rates as a major challenge.

On the challenge of high capital requirements, the respondents ranked it as high $(\mathrm{M}=5.0, \mathrm{SD}=0.764)$. According to the respondents, the capital requirement is essential to keep incapable people out of the industry and to protect clients. However, they conceded that the requirement is too high especially given the seeming lack of confidence and mistrust in the institutions in recent times. It is important to reduce the capital requirements to allow the MFIs enough funds for operation. 
More so, researchers found that low level knowledge of operators was a major challenge MFIs face in the city $(\mathrm{M}=5.0, \mathrm{SD}=0.83)$. The respondents generally said that some operators of MFIs in the city do not have adequate knowledge about the operations of the sector. This agrees with Owusu-Nuamah (2014) who observed that many owners of MFIs in Ghana do not have adequate knowledge about the operations of the sector. What is more, Owusu-Nuamah explains that owners of MFIs run the business as a trade and often lack the capacity to properly analyze the implications of their actions. In a rather tragic description of the situation, Owusu-Nuamah (2014) argued that pieces of advice by young financial professionals to the business are received with disdain by owners of MFIs (Owusu-Nuamah, 2014).

Again, the study revealed that the issue of low credit delivery and management was a challenge bedevilling the institutions. Though it was regarded as a moderate challenge, the respondents believed in order to properly promote the activities of MFIs in the city, there is the need for appropriate delivery and management of credit facilities. This finding confirms a study in Ghana which observed that inadequate credit delivery and management constitutes one of the biggest challenges plaguing MFIs in the country (Boateng et al., 2015).

Also, challenges MFIs face in the city were low repayment rate and erosion of public confidence. It was established that MFIs in Takoradi struggle to recover loans they give out owing to poor repayment by clients. As a challenge, low rate of repayment was ranked as high which is revealing in the context of the sustainability of the institutions. Boateng et al. (2015) found in their study that low repayment of loans is a challenge hindering the sustainability of MFIs in Ghana. In addition, the researchers observed that there was erosion of public confidence in MFIs in the city. The respondents stated that public confidence in MFIs has eroded in recent times owing to the many incidents of collapse of MFIs across the nation. This challenge was seen as high. This finding agrees with Odoom et al. (2019) who asserted that the recent collapse of MFIs in Ghana contributes to low confidence in the institutions. This situation, according to the authors, presents a huge challenge to the continuing relevance of MFIs to the economy of the country.

In the same vein, inadequate employee incentives was a high $(\mathrm{M}=5.0, \mathrm{SD}=0.433)$ challenge the industry was faced with in the city. By implication, employees were not receiving adequate incentives in the institutions. This situation may contribute to high rate of attrition in the industry. This result confirms Mukama et al., as cited in Addo (2014), claim that employee related issues such inadequate employee incentives constitute a big challenge to the operations of MFIs. The finding also coincides with the views expressed by Ikeanyibe (2010) that the problems of MFIs have to do with human resources. The finding also is in line with Odoom, Kyeremeh and Opoku (2014) who observed poor remuneration is a challenge to organizations in Ghana.

Moreover, the respondents indicated that there was limited management support for capacity building in the institutions. They ranked this challenge as high $(\mathrm{M}-5.0, \mathrm{SD}=0.522)$. The study supports the claims made by Ikeanyibe (2010) staff capacity issues are part of the challenges MFIs face in their operations. This situation has a huge toll on the industry including the collapse of some of them (Basu et al., 2004). Also, in their study, Odoom, Opoku and Ayipah (2016) found that staff development receives little support in Ghana. This has led to several staff development challenges in the country.

What is more, the study established that clients faced so much pressure when repaying their credit facilities coupled with limited management capacity. Pressure on credit repayment as a challenge was ranked as high $(\mathrm{M}=5.0, \mathrm{SD}=0.54)$. In essence, although operators and employees have the duty to retrieve the loans given to clients, they admitted that customers under so much pressure when it comes to repayment issues. The respondents indicated that sometimes certain coercive strategies are applied to ensure loan repayment. This finding is in agreement with that of Vethecan (2015) which states that repaying loans obtained from MFIs is characterized by pressure. Vethecan (2015) added that sometimes certain coercive repayment tactics used by MFIs led to panic, and in extreme cases suicide attempt. However, some clients confessed it kept them on their toes. However, the respondents ranked limited management capacity as a moderate challenge the institutions were facing. This implies that although managements of MFIs in the city were perceived to have limited capacity, it was not a high challenge.

The second research objective examined whether or not differences existed in the views of respondents with regard to the challenges MFIs face in their operations. An independent samples t-test was conducted to compare the perception of male and female respondents on the challenges MFIs in Takorad face. The result is presented in Tables 5 and 6 . There was statistically significant difference in scores for males $(\mathrm{M}=59.52, \mathrm{SD}=10.52)$ and females $[\mathrm{M}=63.92, \mathrm{SD}=8.74 ; \mathrm{t}(113)=-1.321, \mathrm{p}=.017]$. 
Table 5: Group Statistics of Sex and Challenges of MFIs to the Economy

\begin{tabular}{|l|l|l|l|l|}
\hline Sex & N & Mean & Std. Deviation & Std. Error Mean \\
\hline Male & 61 & 59.5246 & 10.52237 & 1.34725 \\
\hline Female & 54 & 63.9259 & 8.74988 & 1.19071 \\
\hline
\end{tabular}

Source: Field data (2018)

Table 6: An Independent Sample T-test for Mean Perception of Male and Female Respondents on the Challenges MFIs in Takoradi face

\begin{tabular}{|l|l|l|l|l|l|l|l|}
\hline \multicolumn{1}{|l|}{} & $\begin{array}{l}\text { Levene's Test } \\
\text { for Equality of } \\
\text { Variances }\end{array}$ & \multicolumn{2}{l|}{ t-test for Equality of Means } \\
\hline & F & Sig. & T & Df & $\begin{array}{l}\text { Sig. } \\
(2-\text {-tailed })\end{array}$ & Mean Diff. & Std. Error Diff. \\
\hline Equal variances assumed & 1.730 & .191 & -2.421 & 113 & .017 & -.4 .40134 & 1.81827 \\
\hline Equal variances not assumed & & & -2.448 & 112.580 & .016 & -.4 .40134 & 1.79802 \\
\hline
\end{tabular}

(Statistic is significant at 0.05): $\quad d f=$ degree of freedom

Source: Field data (2018)

Cohen (1988) suggests that (eta squared=.05) represents a medium effect size. Thus, the magnitude of the difference between male and female respondents was moderate. Therefore, the null hypothesis which states that there is no statistically significant difference in perception of male and female respondents on the challenges MFIs in Takorad face is rejected. In other words, male and female respondents perceived the challenges MFIs in Takorad face differently.

The third objective examined whether or not differences existed between educational level of respondents and their views on the challenges MFIs in Takoradi face as summarized in Table 7 . The significance level of 0.247 is greater than the alpha value of 0.05 , which shows that there is no difference between the level of education of respondents and their classification of the challenges MFIs in Takoradi face. In other words, the ANOVA test shows that no significant differences existed between the level of education of respondents and their views on the challenges MFIs in the city face. Subjects were grouped into four, namely, Group 1=SSSCE/WASSCE, Group 2=HND/Diploma, Group 3=First Degree, and Group 4=Second Degree.

Table 7: ANOVA Test of Level of Education of Respondents and their Views on the Challenges MFIs in Takoradi face

\begin{tabular}{|l|l|l|l|l|l|}
\hline & Sum of Squares & Df & Mean Square & F & Sig. \\
\hline Between Groups & 410.000 & 3 & 136.667 & 1.399 & .247 \\
\hline Within Groups & 10845.792 & 111 & 97.710 & & \\
\hline Total & 11255.791 & 114 & & & \\
\hline
\end{tabular}

(Statistic is significant at 0.05): $\quad d f=$ degree of freedom

Source: Field data (2018)

Based on these classifications, the study observed that educational qualifications of respondents did not have any influence on how they perceived the challenges the institutions were faced with in the city. Thus, the views of Group 1 were not different from Group 2, Group 3 and Group 4. Likewise, the views of Group 2 were not different from Group 3 and Group 4, and the views of Group 3 were not different from Group 4.

\section{Conclusions and Recommendations}

MFIs in Ghana face several challenges which may undermine the sustainability of the institutions. In the present study, it was found that MFIs in Takoradi face various challenges including poor macroeconomic policies, poor recovery rate, lack of qualified staff, etc. It was also realized that the core concept of micro financing was being diverted. In terms of intensity, the study discovered that increased competition in the industry, low repayment rates, higher cost of information technology, low level knowledge of operators, inadequate and expensive infrastructure base, high capital requirements, unfavourable regulation and supervision, inadequate employee incentives, and erosion of public confidence in MFIs were ranked as high. Also, poor macroeconomic policy 
framework, low credit delivery and management, limited management capacity, and poaching of competent staff by other microfinance companies were ranked as moderate challenges. A significant difference existed in the perception of male and female respondents on the challenges MFIs in the city faced. However, there was no statistically significant difference in educational qualifications of respondents and their views on the challenges MFIs in Takoradi faced. It is recommended that MFIs should invest in staff development for all levels, from senior level to junior level. It is also recommended that Managements of MFIs should put in place adequate measures to educate their clients on the need to pay their loans and also institute appropriate sanctions to deal with loan defaulters. This will also require MFI to ensure credit worthiness of clients before granting them loans. Besides, the Management of MFIs should collaborate with the government to come with favorable policy frameworks which can help boost confidence in the operations of the industry. Where there is stability in economic growth rate, low inflation and fiscal discipline MFIs can flourish. Again, the Managements of MFIs should come out with appropriate measures to incentivize their employees so as to avoid possible cases of poaching. Bank of Ghana should come out with effective regulatory and supervisory frameworks to improve the operations of the microfinance sector. The government should pay increased attention to the microfinance sector through proper monitoring and supervision and tax incentives given the enormous role the institutions play in the economy of the nation. Finally, the government should design policy frameworks and programmes which can help improve the macro-economic conditions. This will enable MFIs to operate favorably in the economy and ultimately contribute to the growth of the economy.

\section{References}

Adjei, J.K. (2010). Microfinance and poverty reduction: The experience of Ghana. Accra: Bold Communications Limited.

Aggarwal, Y. P. (2008). Meaning of the term-descriptive survey research method'. International Journal of Transformations in Business Management, 1.

Amofa. M. B. (2018). Assessing the state of microfinance institutions in Takoradi. MBA Thesis, GTUC/Coventry University, UK.

Asiama, J. \& Osei, V. (2007). A note on microfinance in Ghana. Bank of Ghana. Available at: https:/www.bog.gov.gh/privatecontent/Research/Working\%20Papers/Microfinancing (1).pdf.

Bank of Ghana (2007). A Note on Microfinance in Ghana. A working paper. Monetary Policy Committee, BOG.

Boateng, I. \& Agyei, A. (2013). Microfinance in Ghana: Development, success factors and challenges. International Journal of Academic Research in Accounting, Finance and Management Sciences, 3(4), $153-160$

Che Yeon-Koo (2002). Joint liability and peer monitoring under group lending. Contributions to Theoretical Economics, 2(1).

Daley-Harris, S. (2005). State of the Microcredit Summit Campaign Report.

GHAMFIN (2016). About GHAMFIN. Available at: http://www.ghamfin.org/about-ghamfin/ [Assessed on $15^{\text {th }}$ July, 2018]

Funds for NGOs (n.d.). Non-Governmental Organizations. Available at: https://www.fundsforngos.org $>$ ngos

International Finance Corporation (2014). Experiences of microfinance institutions serving very small to small enterprises in Latin America. Pennsylvania Avenue, N.W. Washington, D.C. 20433. www.ifc.org.

Marguerite, R., (2001). The microfinance revolution, sustainable finance for the poor Washington DC: Library of Congress cataloging.

Muhammad, S. D. (2010). Microfinance challenges and opportunities in Pakistan. European Journal of Social Sciences, 14(1), 94-97.

Odoom, D., Fosu, O. K., Ankomah, K. \& Amofa, M. B. (2019). Exploring the Contributions of Microfinance Institutions to the Ghanaian Economy: A Study at Takoradi. Journal of Economics and Sustainable Development, 10 (1), Available on: www.iiste.org

Odoom, D., Kyeremeh, C. \& Opoku, E. (2014). Human resource capacity needs at the District Assemblies: A study at Assin South District Assembly in Ghana. Journal of Sustainable Development, 7(5), 177-188

Odoom, D., Opoku, E. \& Ayipah, D. D. (2016). Staff Development Needs at the Colleges of Education in Ghana: Evidence from the Agogo College. International Journal of Innovative Research and Development, 5 (1), 127-137

Opoku Antwi, B. (2015). The failure of Microfinance in Ghana: A case study of Noble Dream Microfinance Limited. Masters' Thesis, Kwame Nkrumah University of Science and Technology: Kumasi.

Schneider, F. (2002): Size and Measurement of the Informal Economy in 110 Countries Around the World. Retrieved from: http://rru.worldbank.org/Documents/PapersLinks/informal_economy

Shreiner, M. (2001). A cost-effective analysis of the Grameen Bank of Bangladesh. Center for Social Development Working Paper, 99-5.

Schreiner, M. \& Colombet, H. (2001). Microfinance, Regulation, and Uncollateralised Loans to Small Producers 
in Argentina.

Shuttleworth, M. (2013). Research Design. Available at: http://explorable.com/descriptive-research-design. Simanowitz, A. (2004). Issues in designing effective Microfinance impact assessment systems. Working $\begin{array}{lllll}\text { Paper } & \text { No. } & \text { from }\end{array}$ http://www.ids.ac.uk/impact/Publications/publications_workingpapers.html

Singh, P. (2016). Understanding the structure of Microfinance Institutions in India and suggesting a Regulatory Framework.

World Bank (2000). World Development Report. New York: Washington DC

World Bank (2005). World Development Report, Washington DC. The World Bank.

Xiaohui, L. \& Chang, S. (2002). The relationship between financial development and economic growth: Evidence from China. Studies in Economics and Finance, 20(1): 76-84.

Zingales, L. (2009). Lin RoundTable: Leave room for growth. Free exchange. Retrieved from: http://www.economist.com/blogs/freeexchange/lin roundTable.www.gufsa.rog.

Zuru, N. L., Hashim, M. K. \& Darwina, A. (2016). A study on the types of microfinance institutions in Nigeria. MAYFEB Journal of Business and Management, 2, 7-16. 